\title{
PENGGUNAAN TEORI HUKUM PERDATA INTERNASIONAL TERHADAP CONFLICT OF LAW DALAM TRANSAKSI ELEKTRONIK
}

\author{
Ria Tri Vinata \\ Fakultas Hukum \\ Universitas Wijaya Kusuma Surabaya
}

\begin{abstract}
Abstraksi
Kegiatan sipil bisa lewat transaksi elektronik dalam bentuk keberadaan kontrak elektronik dan tort perkelahian. Karakter kaya transaksi elektronik tanpa batas (borderless), dapat menghasilkan hukum conflik. Conflik terjadi jika hukum tunduk pada hukum yang berbeda dalam domisili atau kebangsaan, perbuatan hukum yang dilakukan di negara asing, dan konsekuensi hukum yang terjadi di negara-negara asing. Menjelang konflik hukum, Informasi dan Transaksi Elektronik UU 2008 mengatur konflik hukum. Statuta pertama memberikan pihak kebebasan untuk membuat pilihan yang baik dari hukum dan juga forum nya. Kedua, jika pilihan hukum tidak dibuat oleh aturan yang diterapkan dan forum yang bertanggung jawab yang disampaikan pada Teori Hukum Perdata Internasional.
\end{abstract}

Kata Kunci: Konflik Hukum, Hukum Perdata, Transaksi Elektronik

\begin{abstract}
Civil activity can pass transaction of electronic in the form of existence of electronic contract and deed fights against law. Transaction of The electronic haves the character of without bound of state (borderless), hence can generate conflik of law. Conflik of law happened if law subject to differ in domicile or civic, deed of law is done in foreign state, and legal consequences happened in foreign state. Toward conflict of law, Information and electronic transaction Act 2008 arranges about conflict of law. Firstly the statuta gives freedom of the parties to do choice of law either and also its the forum. Second, if choice of law is not done by the parties hences, rule applied and forum in charge delivered at the International Private Law Theory.
\end{abstract}

Key words: Conflict of law, privat law, electronic transaction

\section{PENDAHULUAN}

Perkembangan kemajuan teknologi dewasa ini membawa perubahan pola hidup manusia dalam bergaul, bersosialisasi, bahkan melakukan aktifitas ekonomi dalam skala lokal, regional maupun global (Ade Suherma, 2002;159). Kegiatan sebagaimana tersebut di atas menggunakan suatu hasil dari perkembangan teknologi yang kita kenal dengan internet. Dalam pergaulan individu di internet menghasilkan pola-pola hubungan antar individu yang sifatnya tidak sama dengan apa yang terjadi di dunia riil (Budi Agus Riswandi, 2003;53).

Komputer sebagai alat bantu manusia dengan didukung perkembangan teknologi informasi telah membantu akses ke dalam jaringan jaringan publik (public

\footnotetext{
Penggunaan Teori Hukum Perdata 
network) dalam melakukan pemindahan data dan informasi. Dengan kemampuan komputer dan akses yang semakin berkembang maka transaksi perdagangan pun dilakukan di dalam jaringan komunikasi tersebut. Jaringan publik mempunyai keunggulan dibandingkan dengan jaringan privat dengan adanya efisiensi biaya dan waktu. Hal ini membuat perdagangan dengan transaksi elektronik (Electronic Commerce) menjadi pilihan bagi para pelaku bisnis untuk melancarkan transaksi perdagangannya karena sifat jaringan publik yang mudah untuk diakses oleh setiap orang ataupun perusahaan. Internet yang pada awalnya lahir dari ARPANET, yang merupakan jaringan komputer milik Departeman Pertahanan Amerika Serikat yang ditujukan untuk mempermudah pertukaran informasi di antara para pengkaji pertahanan (defence researchers) berkembang begitu pesat dan bahkan menjadi elan vital bagi kelangsungan kehidupan beberapa kelompok manusia di bumi ini (Budi Agus Riswandi, 2003;13).

Dengan adanya internet, hubungan hukum antara subjek hukum dengan subjek hukum lainnya tidak hanya terjadi secara langsung (face to face), tetapi dapat berlangsung tanpa pertemuan, bahkan dimungkinkan antara satu subyek hukum dengan subyek hukum lainnya tidak saling mengenal.

Salah satu sifat dari media internet adalah sifat borderless atau tanpa batas. Dengan sifat ini, individu yang berinteraksi dan saling berhubungan tidak lagi dibatasi oleh batas negara atau wilayah tertentu, sehingga aktivitas di internet sangat memungkinkan terjadi antara satu individu yang berada di wilayah negara A dan pihak yang lain berada di wilayah negara $\mathrm{B}$.

Perbuatan hukum yang terjadi di internet begitu banyak jumlahnya dan tidak mungkin untuk menguraikannya satu persatu. Berdasarkan ilmu hukum, perbuatan hukum yang dapat menimbulkan perikatan di antaranya melalui perjanjian dan perbutan melanggar hukum. Perjanjian didasarkan pada suatu kesepakatan sedangkan perbuatan melanggar hukum didasarkan pada ketentuan undang-undang.

Semakin konvergennya (keterpaduan) perkembangan Teknologi Informasi dan Telekomunikasi dewasa ini, telah mengakibatkan semakin beragamnya pula aneka jasa-jasa (features) fasilitas telekomunikasi yang ada, serta semakin canggihnya produk-produk teknologi informasi yang mampu mengintegrasikan semua media informasi.

Di tengah globalisasi komunikasi yang semakin terpadu (global communication network) dengan semakin populernya Internet seakan telah membuat dunia semakin menciut (shrinking the world) dan semakin memudarkan batas-batas negara berikut 
kedaulatan dan tatananan masyarakatnya. Ironisnya, dinamika masyarakat Indonesia yang masih baru tumbuh dan berkembang sebagai masyarakat industri dan masyarakat Informasi, seolah masih tampak prematur untuk mengiringi perkembangan teknologi tersebut berdasarkan hasil penelitian oleh group riset Digital dan Security Electronic yang pernah dipresentasikan di hadapan Masyarakat Telekomunikasi Indonesia pada bulan Juni 1999 di Pusat Ilmu Komputer Universitas Indonesia, Depok Jawa Barat, kerangaka hukum digital signature dalam Electrionic Commerce, (lihat>http://www.geocities.com/amwib owo/resource/.htm., 1999;1).

Media elektronik di dalam tulisan ini untuk sementara hanya difokuskan dalam hal penggunaan media internet, mengingat penggunaan media internet yang saat ini paling populer digunakan oleh banyak orang, selain merupakan hal yang bisa dikategorikan sebagai hal yang sedang 'booming'. Begitu pula perlu digarisbawahi, dengan adanya perkembangan teknologi di masa mendatang, terbuka kemungkinan adanya penggunaan media jaringan lain selain internet.

Internet sebagai media global yang digunakan sebagai media dalam berbagai aktivitas, termasuk aktivitas keperdataan seperti jual-beli, iklan, perjanjian, pengiriman data dan berbagai kegiatan keperdataan kecuali bidang hukum keluarga. Di dalam melakukan kegiatan keperdataan tersebut, para pihak mungkin saja berasal dari dua wilayah negara yang berbeda, sehingga apabila timbul seuatu permasalahan antara kedua belah pihak di bidang keperdataan maka menimbulkan berbagai pertanyaan yang terkait dengan hukum perdata internasional yaitu hukum manakah yang akan digunakan dan pengadilan manakah yang berwenang.

Mengenai hal ini, Indonesia belum memiliki peraturan hukum positif mengenai hukum perdata internasional. Akan tetapi pada 2008, Dewan Perwakilan Rakyat Indonesia telah mensahkan Undang-undang nomor 11 Tahun 2008 tentang Informasi dan Transaksi Elektronik yang mengatur aktivitas manusia yang berhubungan dengan teknologi informasi termasuk di dalamnya aktivitas di internet.

Berdasarkan latar belakang di atas, menarik penulis untuk membahas permasalahan maka aktivitas keperdataan apa sajakah yang terjadi di internet yang dapat menimbulkan permasalahan Hukum Perdata Internasional dan Bagaimanakah pengaturan permasalahan Hukum Perdata Internasional yang terjadi di Internet berdasarkan UndangRia Tri Vinata

Penggunaan Teori Hukum Perdata Internasional Terhadap Conflict Of Law Dalam Transaksi Elektronik 
undang Nomor 11 Tahun 2008 tentang Informasi dan Transaksi Elektronik mengatu

\section{KEGIATAN KEPERDATAAN DI INTERNET.}

Perbuatan hukum yang terjadi di internet begitu banyak jumlahnya dan tidak mungkin untuk menguraikannya satu persatu. Berdasarkan ilmu hukum, perbuatan hukum yang dapat menimbulkan perikatan di antaranya melalui perjanjian dan perbutan melanggar hukum. Perjanjian didasarkan pada suatu kesepakatan sedangkan perbuatan melanggar hukum didasarkan pada ketentuan undang-undang. Sebagai media yang terhubung secara global, internet merupakan alat yang efektif untuk melakukan kegiatan di bidang bisnis yang memerlukan kecepatan dan kepraktisan. Saat ini banyak sekali perikatan yang menimbulkan hubungan hukum terjadi dengan segala macamnya di internet.

Para ahli telematika menyebut aktivitas yang menimbulkan hubungan hukum ini sebagai "transaksi elektronik" (Edmund Makarim, 2004;222). Istilah 'transaksi' pada umumnya digunakan dan dipahami oleh masyarakat hanya sebagai kegiatan jual beli antar para pihak yang bersepakat untuk itu saja. Dalam lingkup hukum, sebenarnya istilah transaksi adalah keberadaan suatu perikatan ataupun hubungan hukum yang terjadi antara para pihak.

Berdasarkan perkenbangan yang terjadi, transaksi secara elektronik yang merupakan aktvitas di internet disebut juga dengan istilah online contract.

Menurut Edmon Makarim, online contract sebenarnya adalah hubungan hukum yang dilakukan secara elektronik dengan memadukan jaringan networking) dari sistem informasi berbasis komputer (computer based information system) dengan sistem komunikasi yang berdasarkan atas jaringan dan jasa telekomunikasi (telecomunication based), yang selanjutnya difasilitasi oleh keberadaan jaringan komputer global internet (network of network) (Edmund Makarim, 2004;223). Oleh karena itu, segala macam ketentuan pengenai perikatan berlaku pula dalam aktivitas ini. Berikut dua perbutan hukum yang menimbulkan perikatan dalam transaksi elektronik: (1)Kontrak elektronik Menurut penafsiran yang diberikan Undang-undang Informasi dan Transaksi elektronik pada pasal 1 ayat (8) dijelaskan bahwa kontrak elektronik adalah perjanjian yang dimuat dalam dokumen elektronik atau media elektronik lainnya. Bentuk kongkrit dari kontrak elektronik ini mencakup jual beli, lisensi, asuransi, lelang, dan perjanjianperjanjian lainnya yang berkembang sesuai dengan perkembangan bisnis yang 
ada di masyarakat. Apabila hubungan hukum itu terjadi dengan subyek hukum di luar Indonesia karena sifat internet yang global, maka ini merupakan permasalahan hukum perdata internasional. Permasalahan yang timbul adalah hukum mana yang digunakan dan pada forum mana dapat diajukannya suatu tuntutan hokum. Akan tetapi berdasarkan ketentuan Pasal 5 ayat (4) UU Informasi dan Transaksi Elektronik terdapat pengecualian, tidak semua kontrak yang dibuat dibolehkan. Pengecualian itu :

(a)pembuatan dan pelaksanaan surat-surat terjadinya perkawinan dan putusnya perkawinan; (b)surat-surat yang menurut undang-undang harus dibuat dalam bentuk tertulis; (c)perjanjian yang berkaitan dengan transaksi barang tidak bergerak; (d)dokumen-dokumen yang berkaitan dengan hak kepemilikan; dan (e) dokumen-dokumen lain yang menurut peraturan perundang-undangan yang berlaku mengharuskan adanya pengesahan notaris atau pejabat yang berwenang. (2) Perbuatan Melanggar Hukum. Selama melakukan kegiatan di dunia maya dimungkinkan terjadi Perbuatan Melanggar Hukum. Dalam KUH Perdata tidak didefinisikan istilah perbuatan melanggar hukum tetapi dalam pasal 1365 KUH Perdata menyebutkan " tiap perbuatan melanggar hukum, yang membawa kerugian kepada seorang lain, mewajibkan orang yang karena salahnya menerbitkan kerugian itu, mengganti kerugian tersebut"،

Sejak adanya arrest tahun 1919 suatu perbuatan merupakan perbuatan melanggar hukum apabila melanggar hak orang lain, bertentangan dengan kewajiban hukum si pembuat, bertentangan dengan kesusilaan yang baik, atau bertentangan dengan kepatutan yang terdapat di masyarakat. (Diktat PMH, FH Unsoed). Pada dunia internet pun dapat saja orang berbuat/melakukan tindakan yang mengakibatkan kerugian bagi orang lain. diantaranya : (a)Pencemaran nama baik dengan menggunakan media internet seperti pemberitaan yang berisi fitnah; (b)Hak atas kekayaan intelektual yang terkait dengan internet, seperti menjiplakan domain name, pembajakan software, web desain, dan lain-lain (c)Kejahatankejahatan yang terkait dengan internet (cyber crime), seperti penipuan, perusakan data, dan lain-lain.

Atas tindakan tindakan yang merugikan tersebut dapat saja dilakukan gugatan atas kerugian yang diderita dengan mendasarkan pasal $1365 \mathrm{KUH}$ Perdata sebagai perbuatan melawan hukum (Ahmad M. Ramli, 2004;36).

Dikarenakan internet merupakan media global, maka perbuatan melanggar hukum ini menjadi permasalahan HPI jika di dalamnya 
terkandung unsur-unsur asing. Hal ini dapat terjadi apabila : (i)Pelaku perbuatan berdomisili atau berkewarganegaraan asing; (ii)Tindakan dilakukan di dalam wilayah hukum asing; (iii)Akibat-akibat dari perbuatan timbul di suatu wilayah negara asing; (iv)Pihak yang dirugikan berdomisili atau berwarganegara asing.

\section{PENGATURAN PERMASALAHAN HPI DALAM UNDANG-UNDANG NOMOR 11 TAHUN 2008 TENTANG INFORMASI DAN TRANSAKSI ELEKTRONIK}

Setelah melalui rentang waktu yang panjang, akhirnya Indonesia memiliki perangkat hukum yang mengatur segala aktivitas yang terjadi di intenet yaitu Undang-undang Informasi dan Transaksi Elektronik. Keberadaan undang-undang ini cukup penting bagi Indonesia karena globalisasi informasi telah menempatkan Indonesia sebagai bagian dari masyarakat informasi dunia sehingga mengharuskan dibentuknya pengaturan mengenai pengelolaan informasi dan transaksi elektronik di tingkat nasional sebagai jawaban atas perkembangan yang terjadi baik di tingkat regional maupun internasional. (konsiderans UU ITE).

Internet sebagai media yang berdimensi global yang cakupannya melampaui batas negara tidak luput dari permasalahan hukum yang timbul mengenai hukum negara mana yang berlaku dalam menyelesaikan masalah yang ada di dunia maya. Oleh karena itu Undang-undang Informasi dan Transaksi Elektronik di Indonesia juga mengatur beberapa ketentuan yang terkait dengan hukum perdata internasional. (a)Pilihan Hukum dalam Kontrak Elektronik, Hak dan kewajiban para pihak yang menjadi dasar penyelesaian sengketa mereka dalam conflict of law diistilahkan sebagai choice of law, dan ada pula yang mempergunakan party autonomy. Istilah choice of law lebih pasti pengertiannya dari pada party autonomy, sebagaimana dikemukakan oleh Sudargo Gautama (Sudargo Gautama, 1992;3). Istilah party autonomy sering dipahami secara keliru (misleidend) dalam Hukum Bisnis Internasional, sehingga menimbulkan pemikiran ke arah yang sebenarnya tidak dicakup oleh istilah tersebut. Istilah autonomy (otonom) mengandung pengertian menentukan sendiri hukum yang harus berlaku bagi mereka. Secara hukum para pihak tidak mempunyai kemampuan untuk membuat sendiri undang-undang bagi mereka. Tidak ada kewenangan untuk menciptakan hukum bagi para pihak yang berkontrak. Mereka hanya diberikan kebebasan untuk 
memilih hukum mana yang mereka kehendaki untuk diterapkan bagi kontrak yang mereka buat, dan tidak diberikan kewenangan untuk secara otonom menentukan sendiri hukum yang harus berlaku bagi mereka. Kolleewijn mengemukakan dalam kaitan ini: "Het is slechts kiesvrijheid...Niet het recht tot selfregeling”. (Itu hanyalah kebebasan untuk memilih....bukanlah hak untuk mengatur sendiri) (Abdullah A. Gani, 2005;3).

Pengaturan pilihan hukum atau choice of law dalam Undang-undang Informasi dan Transaksi Elektronik disebutkan dalam Pasal 18 yang selengkapnya sebagai berikut : (i)Para pihak memiliki kewenangan untuk memilih hukum yang berlaku bagi transaksi elektronik internasional yang dibuatnya; (ii)Apabila para pihak tidak melakukan pilihan hukum dalam transaksi elektronik internasional, hukum yang berlaku didasarkan pada asas-asas Hukum Perdata Internasional.

(iii)Para pihak memiliki kewenangan untuk menetapkan forum pengadilan, arbitrase atau lembaga penyelesaian sengketa alternatif yang berwenang menangani sengketa yang mungkin timbul dari transaksi elektronik. (iv)Apabila para pihak tidak melakukan pilihan forum sebagaimana dimaksud dalam ayat (4) penetapan kewenangan pengadilan, arbitrase atau lembaga penyelesaian sengketa alternatif yang berwenang menangani sengketa yang mungkin timbul dari transaksi tersebut, didasarkan pada asas-asas Hukum Perdata Internasional; (v)Transaksi elektronik yang dituangkan dalam kontrak elektronik mengikat para pihak.

Ketentuan ayat (1) di atas merupakan asas yang biasa disebut pacta sun servanda yang terdapat pula dalam pasal 1338 KUH Perdata sebagai dasar berlakunya dan mengikatnya kontrak elektronik bagi para pihak yang membuatnya. Ketentuan ini sebenarnya tidak diperlukan lagi karena pada hakekatnya segala ketentuan umum dalam Buku III KUH Perdata berlaku pula bagi perjanjian-perjanjian atau kontrak-kontrak baik yang ada dalam KUH Perdata maupun perjanjian atau kontrak di luar KUH Perdata sebagaimana dinyatakan dalam Pasal 1319 KUH Perdata.

Terhadap ketentuan di atas penulis menganalisisnya sebagai berikut: (a)Pilihan hukum tersebut harus ada pembatasan. Menurut penulis, ketentuan ayat (2) tidak dapat dipergunakan begitu saja, karena kebebasan memilih hukum tidak bebas sebebas-bebasnya. Jangan sampai pilihan hukum ini hanya dijadikan alat untuk melakukan penyelundupan 
hukum. Kemudian dari pada itu, terdapat beberapa ketentuan yang tidak dapat dilakukan pilihan hukum. misalnya UU Kepailitan, UU Perbankan (termasuk kantor cabang bank asing mengikuti ketentuan ini vide Peraturan Bank Indonesia No. 7/4/PBI/2005 tentang Prinsip Kehati-hatian).

Dalam Sekuritisasi Aset Bank Umum, Hak kekayaan intelektual, PP tentang Waralaba, dan sebagainya serta pembatasan terhadap ketertiban umum (Abdullah A. Gani, 2005;7).

Perlu juga kira Hukum Indonesia menentukan kontrak-kontrak dalam bidang apa saja ynag tidak boleh dilakukan pilihan hukum untuk kepentingan nasional Indonesia. Hal ini seperti yang terdapat dalam ketentuan hukum Cina melarang pelaksanaan choice of law dalam kontrak bisnis yang terkait dengan teknologi. Ketentuan hukum yang dipergunakan adalah hukum Cina. Ketentuan yang ditetapkan oleh Menteri Perdagangan dan Ekonomi Cina itu mengenai kebijakan impor teknologi di RRC. (b)Ketidakjelasan tentang teori HPI.

Pada ayat (2) Pasal 18 dinyatakan tentang kebebasan melakukan pilihan hukum bagi para pihak yang melakukan kontrak elektronik secara internasional. Ketentuan ini dilanjutkan dengan ayat berikutnya yang hanya menyatakan apabila tidak dilakukan pilihan hukum maka berlaku teori-teori dalam hukum perdata internasional. Ketentuan ini menyerahkan penafsiran kepada hakim dan para pihak untuk merumuskan hukum mana yang berlaku jika tidak dilakukan pilihan hukum sesuai dengan teori HPI yang ada.

Ayat (3) yang menyatakan apabila tidak dilakukan pilihan hukum maka penetapan hukum yang berlaku dilakukan berdasarkan prinsip-prinsip atau asas-asas Hukum Perdata Internasional yang akan ditetapkan sebagai hukum yang berlaku pada kontrak tersebut. Arti sesungguhnya adalah pembuat undang-undang menyerahkan kepada doktrin mengenai hukum mana yang diberlakukan dalam perjanjian yang tidak melakukan pilihan hukum.

Berdasarkan teori-teori HPI, ketentuan ayat 2 merupakan pilihan hukum yang dinyatakan secara tegas. Terdapat pula pilihan hukum secara diam-diam yaitu kita dapat menyimpulkan maksud para pihak ini mengenai hukum yang mereka kehendaki dan sikap mereka dari isi dan bentuk perjanjian (Sudargo Gautama, 1977;177). Selain itu pula terdapat pilihan hukum yang dianggap dan pilihan hukum secara hipotesis (Sudargo Gautama, 1977;178179). Ketiga macam pilihan hukum yang terakhir ini sesungguhnya bukanlah 
pilihan hukum, akan tetapi suatu penafsiran berdasarkan asas-asas HPI terhadap perjanjian yang dibuat oleh para pihak jika para pihak tidak menentukan secara tegas pilihan hukumnya. Untuk menentukannya tentunya merupakan kewenangan hakim nantinya apabila terjadi konflik terhadap pelaksanaan maupun isi dari kontrak elektronik yang dibuat secara internasional.

Berdasarkan teori HPI klasik terdapat pula asas lex loci contractus, yang menyatakan bahwa hukum yang berlaku dalam suatu kontrak adalah hukum dimana kontrak itu dibuat. Melihat karakteristik kontrak elektronik yang menggunakan internet sebagai medianya sangat sulit ditentukan tempat terjadinya kontrak. Karena kontrak dibuat tidak dengan bertemunya para pihak di suatu tempat sehingga teori ini harus ditinggalkan dalam kontrak elektronik.

Selain itu terdapat pula teori lex loci solutionis yang menyatakan hukum yang berlaku adalah hukum di mana perjanjian itu dilaksanakan. Penggunaan teori ini untuk menentukan hukum mana yang berlaku dalam kontrak elektronik mengalami kesulitan. Karena pelaksanaan kontrak elektronik terdapat dua macam, pelaksanaan kontrak secara nyata/ secara konvensional, misalnya jual-beli di internet, kontraknya merupa- kan kontrak elektronik yang tidak dapat ditentukan tempatnya tetapi pelaksanaannya berupa pengiriman barang dan penyerahan barang dilakukan secara nyata dan ada pula kontrak elektronik yang pelaksanaannya pun melalui internet, misalnya jual beli domain name. terhadap contoh pertama, teori lex loci solutionis masih dimungkinkan digunakan, akan tetapi terhadap contoh kedua tidak mungkin menentukan tempat pelaksanaan perjanjiannya.

Teori yang terakhir adalah the most characteristic connection. Teori ini menyatakan bahwa menentukan hukum yang berlaku didasarkan pada titik taut yang paling berkarakter. Di dalam pandangan ini maka perlu diperhatikan pihak mana dalam suatu hubungan perjanjian mempunyai kewajiban untuk melakukan prestasi yang paling karakteristik (lihat Rancangan HPI Sudargo Gautama, tanpa tahun;1). Contohnya jual beli, dipakai hukum dari pihak penjual karena si penjualah yang memiliki kewajiban paling berkarakter. Akan tetapi dalam kenyataannya sangat sulit menentukan mana pihak yang mempunyai karakter lebih khas daru yang lainnya, bukankah dalam perjanjian berlaku asas keseimbangan. (a)Mengenai Pilihan Forum, Ketentuan ayat 4 dan ayat 5 pada pasal 18 di atas menjelaskan mengenai forum mana yang 
digunakan dalam penyelesaian konflik nantinya. Berdasarkan ayat 4 , forum yang berwenang mengadili sengketa kontrak internasional termasuk yang dilakukan secara elektronik adalah forum yang dipilih oleh para pihak. Forum itu dapat berbentuk pengadilan, arbitrase, atau forum penyelesaian sengketa alternatif. Ketentuan ini memberikan kebebasan para pihak dalam kontrak elektronik untuk menentukan lembaga penyelesaian sengketa yang mereka kehendaki dalam menyelesaikan permasalahan yang mungkin timbul nantinya. Pada ayat 5 nya, lagi-lagi undang-undang ini menyerahkan ketentuan mengenai forum yang bersenang kepada asas dan teori HPI yang ada jika para pihak tidak menentukannya.

Melihat ketentuan Pasal 36 UU

No. 11 tentang ITE menyebutkan: (i)Gugatan perdata dilakukan sesuai dengan Peraturan Perundang-undangan yang berlaku; (ii)Selain penyelesaian gugatan perdata sebagaimana dimaksud dalam ayat (1) para pihak dapat menyelesaikan sengketa melalui lembaga penyelesaian sengketa alternatif atau arbitrase sesuai peraturan perundangundangan yang berlaku.

Mengenai gugatan perdata, tentunya kita di Indonesia berpedoman pada hukum acara perdata yang berlaku yang memiliki asas gugatan disampaikan di wilayah hukum di mana tergugat berada. Apabila tergugat berada diluar wilayah Indonesia maka gugatan dapat diajukan pada wilayah hukum pengadilan Negeri Jakarta Pusat. Selain gugatan di Pengadilan, para pihak juga dapat memilih lembaga arbitrase atau lembaga penyelesaian sengketa alternatif lainnya. (a)Conflict of Law pada Perbuatan Melanggar Hukum, Sebagaimana telah dibahas di atas, selama melakukan kegiatan di dunia maya dimungkinkan terjadi Perbuatan Melanggar Hukum. Di dalam Undang-undang Informasi dan Transaksi Elektronik terdapat beberapa larangan atau perbuatan yang dilarang yang tercantum dalam bab VII. Hal tersebut sebagai tercantum dalam Pasal 26 hingga Pasal 34 UU Nomor 11 Tahun 2008. Oleh karena internet merupakan media global, maka perbuatan melanggar hukum atas pelanggaran ini menjadi permasalahan hukum perdata internasional jika di dalamnya terkandung unsur-unsur asing. Permasalahan yang timbul adalah hukum mana yang berlaku. Ketentuanketentuan dalam Undang-undang Nomor 11 Tahun 2008 tentang Informasi dan Transaksi Elektronik tidak membahas permasalahan ini secara jelas. Berdasarkan teori HPI, sejak dahulu kala digunakan asas lex locus delicti. Asas ini menyatakan bahwa hukum yang berlaku adalah hukum 
tempat dimana terjadinya perbuatan melanggar hukum itu. Jika kita hubungkan dengan karakter aktivitas di internet maka tempat terjadinya perbuatan melanggar hukum itu menjadi suatu permasalahan.

Di dalam menentukan di mana tempat terjadinya perbuatan melanggar hukum terjadi, terdapat beberapa teori: (i)Teori Perbuatan, teori ini mengatakan bahwa tempat perbuatan melanggar hukum itu terjadi adalah di tempat perbuatan itu dilaksanakan; (ii)Teori alat atau teori instrumen, teori ini menjelaskan bahwa tempat terjadinya perbuatan melaanggar hukum adalah tempat di mana alat yang digunakan untuk melakukan perbuatan tersebut bekerja; (iii)Teori akibat, teori ini menjelaskan bahwa tempat terjadinya perbuatan melanggar hukum adalah tempat di mana akibat dari perbuatan itu terjadi.

Berdasarkan teori-teori di atas, apabila terjadi perbuatan melanggar hukum di internet maka terdapat dua kemungkinan hukum yang berlaku. Kemungkinan pertama didasarkan pada teori perbuatan dan teori alat/instrumen. Tempat perbuatan dan tempat alatnya bekerja yaitu seperangkat komputer dan alat komunikasi berada dalam satu tempat yaitu tempat pelaku melakukan perbuatan melanggar hukum. Contohnya seseorang yang melakukan perusakan (hack) di luar negeri terhadap web domain milik perusahaan di Indonesia. Maka, tempat perbuatan melanggar hukumnya yaitu wilayah negara di mana pelaku berbuat. Kemungkinan kedua didasarkan pada teori akibat. Berdasarkan teori ini tempat perbuatan melanggar hukumnya adalah di tempat akibat dari perbuatan itu terjadi. Berdasarkan contoh di atas maka tempat perbuatan itu terjadi adalah di Indonesia.

Melihat ketentuan pasal 2 Undangundang Informasi dan Transaksi Elektronik yang berbunyi : "Undangundang ini berlaku untuk setiap orang yang melakukan perbuatan hukum sebagaimana diatur dalam undangundang ini, baik yang berada di wilayah Indonesia maupun di luar Indonesia, yang memiliki akibat hukum di Indonesia."

Berdasarkan ketentuan pasal diatas, cakupan berlakunya UndangUndang ini sangat luas, bukan saja bagi perbuatan yang dilakukan di wilayah Republik Indonesia tetapi juga berlaku bagi suatu perbuatan yang berakibat hukum di Indonesia. Berdasarkan penafsiran sistematik, maka hukum yang berlaku bagi perbuatan melanggar hukum yang terjadi di internet adalah hukum di mana akibat dari perbuatan melanggar hukum itu terjadi.

\section{PENUTUP}


Berdasarkan pemaparan sebelumnya, maka dapat diketahui bahwa terdapat beberapa perbuatan yang menimbulkan perikatan dan hubungan hukum dalam kegiatan manusia menggunakan internet yang disebut online contract yang terdiri dari kontrak elektronik dan perbuatan melanggar hukum. Terhadap aktifitas tersebut, Undang-Undang Nomor 11 Tahun 2008 tentang Informasi dan Transaksi Elektronik mengatur ketentuanketentuan dalam hukum perdata internasonal yaitu, pilihan hukum dalam kontrak elektronik internasional; penggunaan teori-teori Hukum Perdata Internasional; pilihan forum penyelesaian sengketa; dan lingkup berlakunya Undnag-undang ini terhadap perbuatan melanggar hukum yang berakibat di Indonesia

Berkaitan dengan ketentuanketentuan hukum perdata internasional dalam Undang-undang Nomor 11 Tahun 2008 tentang ITE terdapat beberapa kekurangan, menyarankan untuk segera dibuat undang-undang tentang Hukum Perdata Internasional Indonesia yang mencakup secara menyeluruh permasalahan-permasalahan Hukum Perdata Internasional Indonesia agar terciptanya kepastian hukum dalam hal keperdataan yang terkait dengan sistem hukum asing.

\section{DAFTAR PUSTAKA}

Ahmad M. Ramli,(2004), Cyber Law dan HAKI dalam Sistem Hukum Indonesia, Refika Aditama, Bandung

Gautama, Sudargo,(1997), Pengantar Hukum Perdata Internasional, Bina Cipta, Bandung

_-, (1992), Hukum Perdata Internasional, Jilid II Bagian 4 Buku ke 5, Alumni, Bandung

_, Rancangan Undang Hukum Perdata Internasional Indonesia, tanpa tahun.

Gani, Abdullah A., (2005),Pandangan Yuridis Conflict of Law dan Choice of Law dalam Kontrak Bisnis Internasional, Buletin Perbankan dan Kebanksentralan, Volume 3 Nomor 3 Tahun 2005

Makarim, Edmund,(2004), Kompilasi Hukum Telematika, Rajawali Press, Jakarta

Riswandi, Budi Agus,(2003), Hukum dan Internet di Indonesia, UII Press, Yogyakarta

Suherman, Ade Maman, (2002),Aspek Hukum Dalam Ekonomi Global, Ghalia Indonesia, Jakarta. 